\title{
Erratum to: Evidence for Contributions of Gut Microbiota to Colorectal Carcinogenesis
}

\author{
Tyler Culpepper • Volker Mai
}

Published online: 23 February 2013

(C) Springer Science+Business Media New York 2013

Erratum to: Curr Nutr Rep (2013) 2:10-18

DOI 10.1007/s13668-012-0032-0

The name of the first author was mistakenly written as "B.S. Tyler Culpepper" in the original version of this article that published in Current Nutrition Reports, Volume 2, Issue 1 (March 2013). The name shown is now correct.

The online version of the original article can be found at http://dx.doi.org/ 10.1007/s13668-012-0032-0.

T. Culpepper

Department of Microbiology and Cell Sciences, IFAS,

Gainesville, FL, USA

V. Mai $(\bowtie)$

Department of Epidemiology, College of Public Health and Health

Professions and College of Medicine and Emerging

Pathogens Institute, University of Florida,

Gainesville, FL 32610, USA

e-mail: vmai@ufl.edu 